\title{
Zinc homeostasis and signaling in health and diseases
}

\section{Zinc signaling}

\author{
Toshiyuki Fukada $\cdot$ Satoru Yamasaki $\cdot$ \\ Keigo Nishida $\cdot$ Masaaki Murakami • \\ Toshio Hirano
}

Received: 24 March 2011/Accepted: 9 May 2011/Published online: 10 June 2011

(C) The Author(s) 2011. This article is published with open access at Springerlink.com

\begin{abstract}
The essential trace element zinc ( $\mathrm{Zn})$ is widely required in cellular functions, and abnormal $\mathrm{Zn}$ homeostasis causes a variety of health problems that include growth retardation, immunodeficiency, hypogonadism, and neuronal and sensory dysfunctions. $\mathrm{Zn}$ homeostasis is regulated through $\mathrm{Zn}$ transporters, permeable channels, and metallothioneins. Recent studies highlight Zn's dynamic activity and its role as a signaling mediator. $\mathrm{Zn}$ acts as an intracellular signaling molecule, capable of communicating between cells, converting extracellular stimuli to intracellular signals, and controlling intracellular events. We have proposed that intracellular $\mathrm{Zn}$ signaling falls into two
\end{abstract}

This article is part of a JBIC special issue on metallothioneins.

T. Fukada $\cdot$ S. Yamasaki $\cdot$ K. Nishida $\cdot$ T. Hirano

Laboratory for Cytokine Signaling,

RIKEN Research Center for Allergy and Immunology,

Yokohama, Kanagawa 230-0045, Japan

T. Fukada

Laboratory of Allergy and Immunology,

Graduate School of Medicine,

Osaka University,

Osaka 565-0871, Japan

K. Nishida

Immune System, Cooperation Program, Graduate School of Frontier Biosciences,

Osaka University, Osaka 565-0871, Japan

M. Murakami · T. Hirano $(\square)$

Laboratories of Developmental Immunology,

JST-CREST, Graduate School of Frontier Biosciences,

Graduate School of Medicine,

WPI Immunology Frontier Research Center,

Osaka University, Osaka 565-0871, Japan

e-mail: hirano@molonc.med.osaka-u.ac.jp classes, early and late $\mathrm{Zn}$ signaling. This review addresses recent findings regarding $\mathrm{Zn}$ signaling and its role in physiological processes and pathogenesis.

Keywords Zinc $\cdot$ Signaling $\cdot$ Zinc transporter . Metallothionein · Disease

$\begin{array}{ll}\text { Abbreviations } \\ \text { BMP } & \text { Bone morphogenetic protein } \\ \text { Ca } & \text { Calcium } \\ \text { cAMP } & 3^{\prime}, 5^{\prime} \text {-Cyclic adenosine monophosphate } \\ \text { cGMP } & 3^{\prime}-5^{\prime} \text {-Cyclic guanosine monophosphate } \\ \text { CIA } & \text { Collagen-induced arthritis } \\ \text { EAE } & \text { Experimental autoimmune encephalomyelitis } \\ \text { Erk1/2 } & \text { Extracellular signal-regulated kinase 1 and } 2 \\ \text { EZS } & \text { Early zinc signaling } \\ \text { FceRI } & \text { Fc epsilon receptor I } \\ \text { FGFR } & \text { Fibroblast growth factor receptor } \\ \text { GPCR } & \text { G protein-coupled receptor } \\ \text { GPR39 } & \text { G protein-coupled receptor 39 } \\ \text { gp130 } & \text { Glycoprotein 130 } \\ \text { IL-6 } & \text { Interleukin-6 } \\ \text { KO } & \text { Knockout } \\ \text { LPS } & \text { Lipopolysaccharide } \\ \text { LZS } & \text { Late zinc signaling } \\ \text { mRNA } & \text { Messenger RNA } \\ \text { MT } & \text { Metallothionein } \\ M T 1 / 2-K O & M T 1 \text { and } M T 2 \text { double knockout } \\ \text { NF- } \kappa \text { B } & \text { Nuclear factor kappa B } \\ \text { NO } & \text { Nitric oxide } \\ \text { PKC } & \text { Protein kinase C } \\ \text { ROS } & \text { Reactive oxygen species } \\ \text { SNOC } & S \text {-nitrosocysteine } \\ \text { STAT3 } & \text { Signal transducers and activators } \\ & \text { transcription } 3 \\ & \end{array}$


TGF- $\beta \quad$ Transforming growth factor beta

TNF- $\alpha \quad$ Tumor necrosis factor alpha

Th17 T helper 17

TLR Toll-like receptor

Zn Zinc

ZIP Zrt/Irt-like protein

\section{Introduction}

The presence of zinc ( $\mathrm{Zn}$ ) was discovered in Aspergillus niger, the common bread mold, in the nineteenth century [1]. Zn was not recognized as indispensable for human life for almost another 100 years until the important discovery by Prasad et al. [2]. Although $\mathrm{Zn}$ salts and $\mathrm{Zn}$-related compounds are normally colorless, unlike those of metals such as copper and iron, making a biological study of $\mathrm{Zn}$ more difficult, recent advances in life science research have contributed to unfolding its basic requirement for mammalian life [3], including the fact that $\mathrm{Zn}$ is pivotal for mammalian oocytogenesis, even before conception $[4,5]$.

The essential trace element $\mathrm{Zn}$ is a structural constituent in numerous proteins, including growth factors, cytokines, receptors, enzymes, and transcription factors belonging to cellular signaling pathways, and is essential for their biological activity [6, 7]. Emphasizing Zn's physiological relevance to life, a human genome bioinformatics study revealed that approximately $10 \%$ of all proteins may bind with $\mathrm{Zn}$ [8]. The biological functions of these Zn-binding proteins would be maintained through cellular $\mathrm{Zn}$ levels, which are tightly controlled by $\mathrm{Zn}$ transporters and channels, and by $\mathrm{Zn}$-sensing molecules such as metallothioneins (MTs) and metal-responsive-element-binding transcription factor-1 [9-14] (Fig. 1).

Although many studies have focused on $\mathrm{Zn}$ homeostasis and its biological relevance, recent advances in cell biology and chemistry have highlighted the existence and activity of free or labile $\mathrm{Zn}$ in cellular responses, particularly its neurotransmitter activity in synaptic vesicles [15, 16]. Dynamic changes in $\mathrm{Zn}$ levels in the brain correlating to physiological experiences and long-term memories have been documented [17, 18], suggesting that free $\mathrm{Zn}$ is closely involved in neurotransmitter functions. There is increasing evidence that $\mathrm{Zn}$ not only acts as a neurotransmitter to mediate intercellular communication, but also acts as an intracellular signaling molecule, much like calcium (Ca) [19]. Our observation that nuclear retention of the $\mathrm{Zn}$-finger transcription factor Snail requires the $\mathrm{Zn}$ transporter Zrt/Irt-like protein (ZIP) 6/Liv1, which in the zebrafish gastrula organizer depends on signal transducers and activators of transcription 3 (STAT3) activation (Fig. 2a) [20], led to a hypothesis that $\mathrm{Zn}$ acts as an intracellular signaling molecule. In this case, intracellular $\mathrm{Zn}$ levels might change in response to extracellular stimuli through changes in $\mathrm{Zn}$ transporter expression, affecting the

Fig. 1 Subcellular localization of zinc $(\mathrm{Zn})$ transporters and metallothioneins (MTs). Localization and potential functions of $\mathrm{Zn}$ transporters from the Slc39/Zrt/Irt-like protein $(Z I P)$ (blue) and Slc30/ $\mathrm{ZnT}$ (red) families, MT, and metal-responsive-elementbinding transcription factor 1 (MTF1) within the cell, based on currently available information [30, 148-154]. Arrows show the predicted direction of $\mathrm{Zn}$ mobilization. ER endoplasmic reticulum

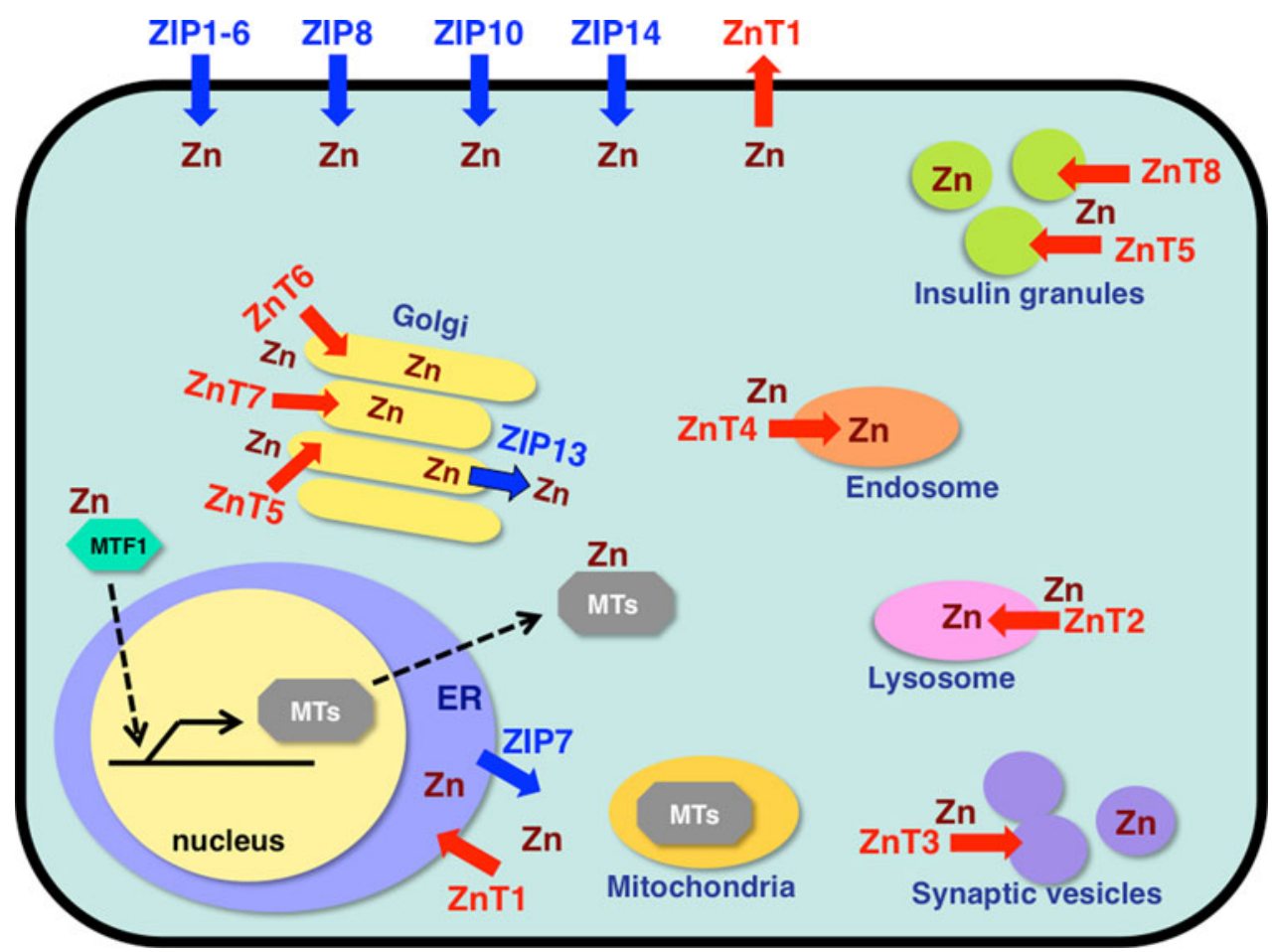




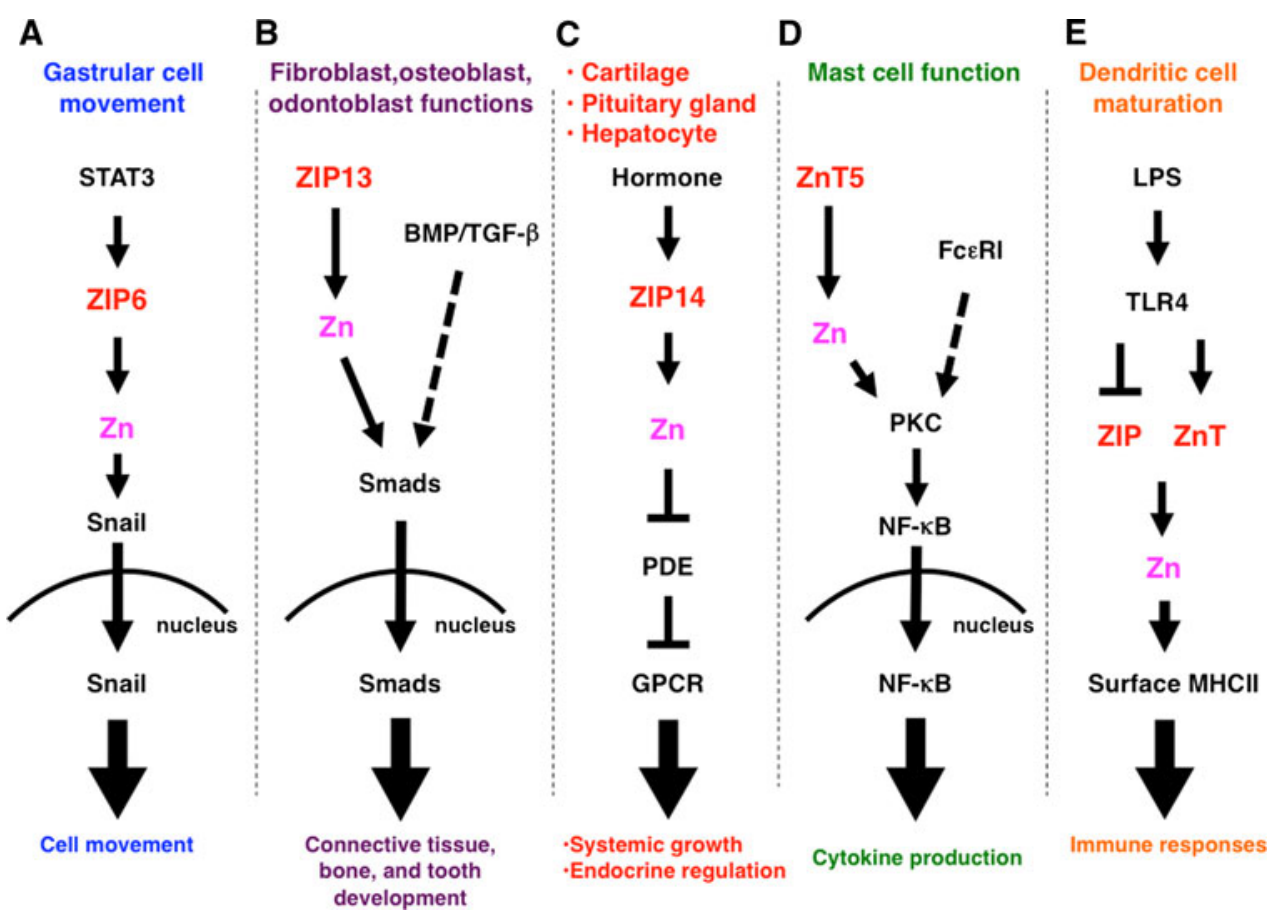

Fig. 2 Roles of ZIP and ZnT Zn transporter family members in intracellular signaling. a The signal transducers and activators of transcription 3 (STAT3) downstream target ZIP6 is required for nuclear translocation of the Zn-finger transcription factor Snail, which regulates gastrular cell movement in zebrafish. b ZIP13 is required for the nuclear translocation of Smads in bone morphogenetic protein $(B M P) /$ transforming growth factor beta $(T G F-\beta)$ signaling, and is involved in tooth, bone, and connective tissue development. c ZIP14, which facilitates $\mathrm{G}$ protein-coupled receptor $(G P C R)$ signaling by inhibiting hormone-stimulated phosphodiesterase $(P D E)$ in the

activation status of several intracellular signaling molecules, including Snail. There is growing evidence that $\mathrm{Zn}$ mediated by $\mathrm{Zn}$ transporters contributes to the regulation of intracellular signaling pathways (Fig. 2a-e), as we will discuss shortly.

We have proposed classifying intracellular $\mathrm{Zn}$ signals into transcription-independent early $\mathrm{Zn}$ signaling (EZS) and transcription-dependent late $\mathrm{Zn}$ signaling (LZS) [19] (Fig. 3). EZS occurs in the "Zn wave" phenomenon in mast cells, in which $\mathrm{Zn}$ levels change rapidly (within several minutes) upon extracellular stimulation [21]. In LZS, the intracellular Zn levels are altered several hours after extracellular stimulation, through changes in $\mathrm{Zn}$ transporter expression. Since many cytosolic proteins may have Zn-binding potential, both EZS and LZS are expected to be closely involved in a wide range of physiological responses, including development, immune functions, cancer progression, and hard and connective tissue disorders [19, 22-24].

Here, we review new findings on the role of $\mathrm{Zn}$ signaling in physiological processes and disease status, and discuss the impact of EZS and LZS on biological events. pituitary gland, liver, and cartilage, is required for endocrine reactions and systemic growth. d ZnT5 controls protein kinase C $(P K C)$ translocation to the plasma membrane, leading to nuclear factor kappa $\mathrm{B}(N F-\kappa B)$-mediated cytokine production in mast cells under $\mathrm{Fc}$ epsilon receptor I (Fc\&RI) signaling. e Lipopolysaccharide (LPS) stimulation alters the expression of ZIP and ZnT family $\mathrm{Zn}$ transporters, resulting in downregulated intracellular $\mathrm{Zn}$ levels, followed by dendritic cell maturation and immune responses. TLR Toll-like receptor

\section{Zn transporters and MTs in Zn homeostasis, health, and disease}

Zn has wide-ranging effects on cellular functions [25, 26], and imbalances in its homeostasis cause various types of abnormalities in humans and in animal models [2, 15, 27]. The intracellular and extracellular $\mathrm{Zn}$ concentration and distribution is controlled by MTs [28], and by Zn transporters of the Slc39/ZIP and Slc30/ZnT families; these transporters increase and decrease, respectively, the cytosolic Zn level [29, 30] (Fig. 1).

Molecular and genetic advances have uncovered the biological significance of $\mathrm{Zn}$ transporters. Mice with a targeted disruption of ZIP1, ZIP2, or ZIP3 are sensitive to dietary $\mathrm{Zn}$ deficiency during pregnancy [31,32]. Mutations in the human ZIP4 gene cause the inherited disorder acrodermatitis enteropathica $[33,34]$, in which the intestine's ability to absorb dietary $\mathrm{Zn}$ is impaired. ZIP13knockout (KO) mice suffer from disorganization in hard and connective tissues, including bone, teeth, skin, and eyes [23, 24]. ZIP13 is involved in bone morphogenetic protein (BMP)/transforming growth factor beta 
Fig. 3 Early and late $\mathrm{Zn}$ signaling. Intracellular $\mathrm{Zn}$ signaling falls into two types: early $\mathrm{Zn}$ signaling (left), in which an extracellular stimulus directly induces elevated $\mathrm{Zn}$ levels within several minutes by releasing $\mathrm{Zn}$ from a $\mathrm{Zn}$ store such as ER or MTs, and late Zn signaling (right), which is induced several hours after stimulation and is dependent on a transcriptional change in $\mathrm{Zn}$ transporter expression. $\mathrm{Zn}$ waves in mast cells are an example of early $\mathrm{Zn}$ signaling (see Fig. 6)

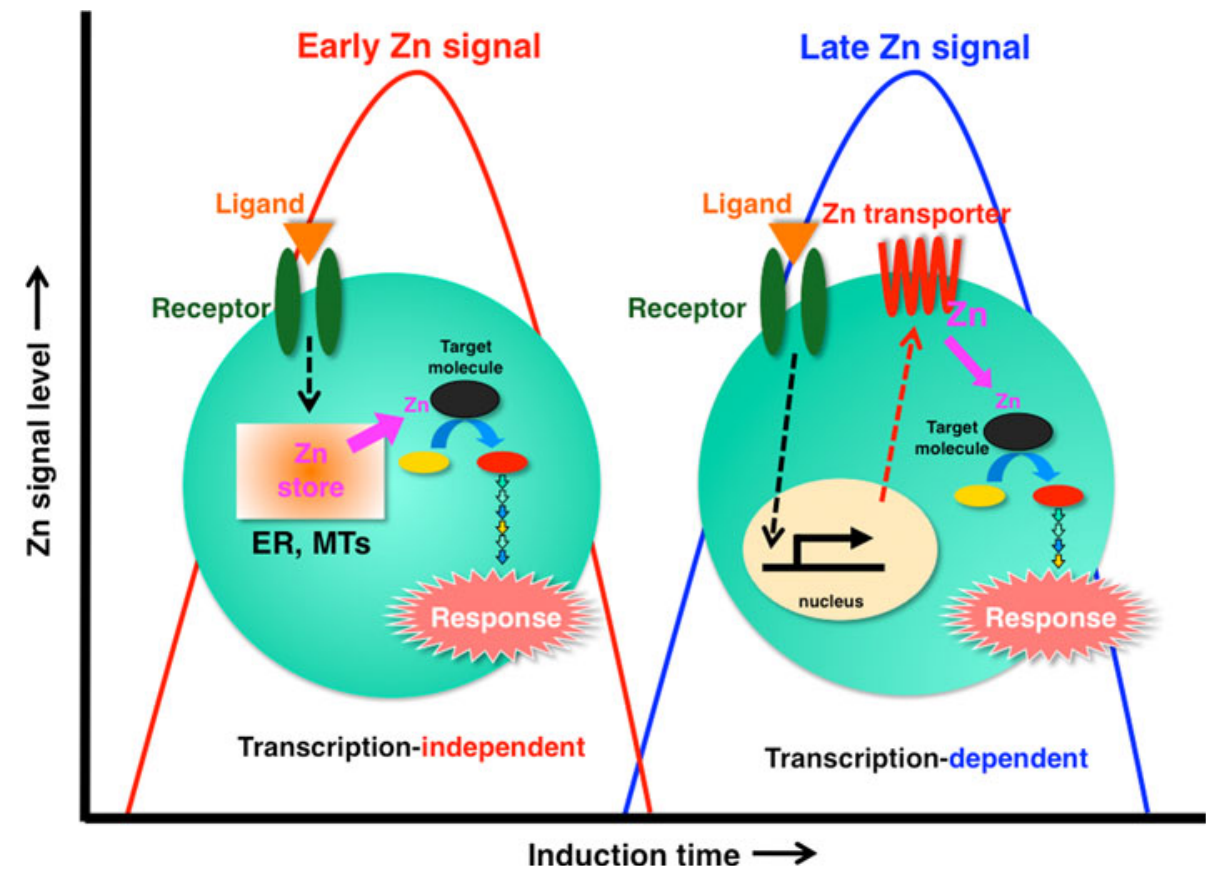

(TGF- $\beta$ )-mediated Smad localization to the nucleus [23] (Fig. 2b). In humans, the loss of ZIP13 function causes the spondylocheiro dysplastic form of Ehlers-Danlos syndrome [23, 35]. ZIP14-KO mice exhibit retarded growth and impaired gluconeogenesis, and ZIP14 has been shown to regulate $\mathrm{G}$ protein-coupled receptor (GPCR) signaling, including that through the parathyroid hormone receptor 1 , growth hormone releasing hormone receptor, and glucagon receptor, by inhibiting phosphodiesterase activity (Fig. 2c) [36]. The lethal milk mutant mice, which have a ZnT4 lossof-function mutation, suffer from an inherited $\mathrm{Zn}$ deficiency in the milk [37]. A similar abnormality, in which a $Z n T 2$ loss-of-function mutation reduces the concentration of $\mathrm{Zn}$ in the milk, has been found in a human case [38]. $\mathrm{ZnT} 8$ is an islet $\beta$-cell-specific $\mathrm{Zn}$ transporter that provides $\mathrm{Zn}$ to form insulin complexes [39]; its single-nucleotide polymorphism is associated with type 2 diabetes [40], and its deletion is accompanied by impaired insulin secretion [41]. ZnT5-KO mice suffer from growth retardation and osteogenic problems [42], and exhibit impaired cytokine production in mast cells [43] (Fig. 2d).

Molecular and genetic approaches using fruit flies have contributed to our understanding of $\mathrm{Zn}$ transporter roles. The Drosophila gene fear of intimacy, which shares similarities with mammalian ZIP6/Liv1 and ZIP10 [44], is essential for proper gonad formation, E-cadherin expression, and glial cell migration [45-47]. Zebrafish Liv1 controls the epithelial-mesenchymal transition under STAT3 activation [20] (Fig. 2a), suggesting that ZIP6 and/ or ZIP10 may have critical roles in cell migration; this was also supported by studies using mammalian cells [48]. The
Drosophila counterpart of ZIP7, Catsup, controls melanin synthesis [49]. Investigation of the Drosophila breathless mutant, which lacks functional fibroblast growth factor receptors (FGFRs), suggested that Catsup protein facilitates FGFR signaling by inhibiting FGFR protein downregulation [50]. A functional connection between ZIP7 and signaling was proposed by a study using cancer cells; ZIP7 positively regulates tyrosine kinases through $\mathrm{Zn}$ inhibition of protein tyrosine phosphatases [51]. These reports indicate that ZIP7's importance in various biological events may be evolutionarily conserved.

MT molecules are also important in $\mathrm{Zn}$ homeostasis [28]; they will be only briefly mentioned here, since they are well described in other articles in this volume. MT was first discovered as a cadmium-binding protein in horse kidneys [52]. Their unique cysteine-rich structure, $\mathrm{Zn}$ binding ability, and expression regulation have drawn many researchers to study MTs, and genetic advances using mouse models have enlarged our understanding of MT activity both in physiological and pathogenic processes such as inflammation. MTs protect against fibrinolytic disturbance and organ damage induced by the bacterial endotoxin lipopolysaccharide (LPS) and ozone $\left(\mathrm{O}_{3}\right)$ [53]. MTs may protect against allergic inflammation through their antioxidant potential, and by suppressing inflammatory cytokines, including interleukin-1 beta [54]. MT defects may cause severe inflammatory responses in multiple sclerosis, Helicobacter-induced gastritis, and LPSmediated lung injury [55-57], suggesting that MTs and Zn may coordinate to protect against various inflammatory conditions in mice [58]. Collectively, these reports strongly 
suggest that MTs and Zn transporters are linked with a wide variety of biological events, disorders, and regulatory functions.

\section{Zn in allergy and immunology}

Zn deficiency in humans accompanies many chronic diseases and is frequently a dietary problem. $\mathrm{Zn}$ homeostasis experiments using mouse models appear to be ideal for determining the impact of a single element nutritional deficiency on immune function, at both the cellular level and the molecular level [59]. Numerous results from animal models have confirmed that $\mathrm{Zn}$ deficiency induces thymic atrophy and lymphopenia, compromises cell- and antibody-mediated responses, and results in increased infection rates and durations [60-64].

Intracellular $\mathrm{Zn}$ levels and distribution have been investigated using $\mathrm{Zn}$ probes, which enable the imaging of distinct pools of $\mathrm{Zn}$ in allergy-related cells. For instance, mast cell granules fluoresce intensely with zinquin [65]. Airway epithelial cells are also rich in $\mathrm{Zn} \mathrm{[66].} \mathrm{In} \mathrm{addition,}$ $\mathrm{Zn}$ is found in the intracellular and extracellular matrix and accumulates in skin tissues following injury [67]. Furthermore, $\mathrm{Zn}$ accelerates wound healing and the reepithelialization process [68, 69]. It has been reported that $\mathrm{Zn}$ deficiency increases allergic eosinophilic inflammation, whereas dietary $\mathrm{Zn}$ supplementation attenuates its intensity [70]. Zn deficiency is a risk factor for developing asthma $[71,72]$. These reports suggest that $\mathrm{Zn}$ is involved in the development of allergic disease. In addition, high levels of ZIP2 messenger RNA (mRNA) are found in the leukocytes of asthmatic infants [73]. However, the precise roles of $\mathrm{Zn}$ and $\mathrm{Zn}$ transporters in allergy-related cells are not well understood.

We found that $\mathrm{Zn}$ is involved in regulating allergic response in mast cells [74]. In these cells, $\mathrm{Zn}$ chelators inhibit histamine release, cytokine production, and lipid mediator secretion, and these inhibitory effects are rescued by $\mathrm{Zn}$ supplementation. Other metal chelators do not affect mast cell function. These results indicate that $\mathrm{Zn}$ is crucial for mast cell degranulation and for cytokine production. Similarly, depleting $\mathrm{Zn}$ with a $\mathrm{Zn}$ chelator, or with the clinically used heavy-metal chelator 2-3-dimercaptopropane-1-sulfonate, inhibits the mRNA expression of chemokines such as eotaxin in human lung cell lines [75]. Recently, Nishida et al. [43] reported that ZnT5 plays crucial roles in mast cell activation and mast cell-mediated allergic reactions (Fig. 2d). ZnT5 mRNA is highly expressed in mast cells, and its level is enhanced by Fc epsilon receptor I (FceRI) stimulation, suggesting that ZnT5 is involved in FceRI-mediated allergic reactions. ZnT5-KO mice have defects in mast cell delayed-type allergic reactions such as contact hypersensitivity, but not in immediate-type reactions such as anaphylaxis [43]. Consistent with this in vivo analysis, ZnT5 is required for FceRI-mediated cytokine production but not for degranulation in mast cells. In ZnT5-KO mast cells, FceRI-induced interleukin-6 (IL-6) and tumor necrosis factor alpha $(T N F-\alpha)$ mRNA are reduced. Furthermore, the FceRI-induced translocation of protein kinase $\mathrm{C}$ (PKC) to the plasma membrane and the translocation of nuclear factor kappa B $(\mathrm{NF}-\kappa \mathrm{B})$ to the nucleus are impaired in ZnT5-KO mast cells. Thus, ZnT5 is selectively needed for mast cell-mediated delayed-type allergic responses, and is a novel player in $\mathrm{PKC} / \mathrm{NF}-\kappa \mathrm{B}$ signaling. This raises the question, presently unanswered, of how ZnT5 regulates the plasma membrane translocation of PKC. PKC contains Zn-binding motifs in its phorbol 12-myristate 13-acetate binding sites, and $\mathrm{Zn}$ is essential to its structure [76, 77]. Mutational analysis shows that PKC's Zn-binding site is essential for PKC's translocation to the plasma membrane (Fig. 4), suggesting a crucial link between ZnT5 and PKC activation.

In addition to its role in allergy-related cells, $\mathrm{Zn}$ is involved in the control of both dendritic and $\mathrm{T}$ cells. The

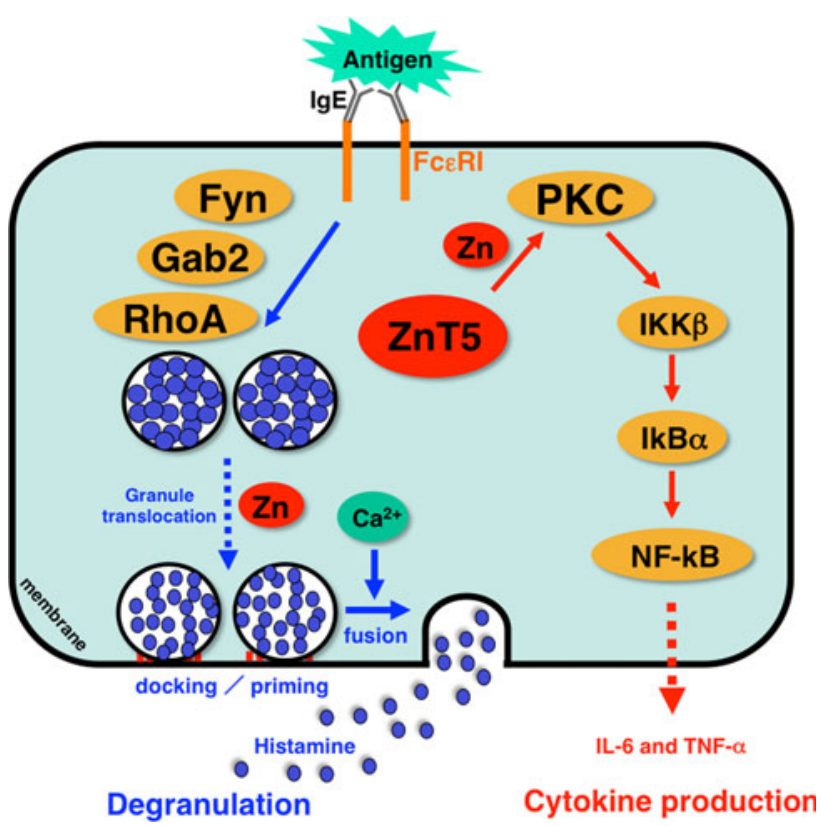

Fig. $4 \mathrm{Zn}$ and $\mathrm{Zn}$ transporters are indispensable for FceRI-mediated mast cell activation. $\mathrm{Zn}$ is required for multiple steps of FceRIinduced mast cell activation, including degranulation and cytokine production. Cytosolic Zn regulates the FceRI-induced granule translocation process, which is mediated by a Fyn/Grb2-associated binder $2(G a b 2) /$ Ras homologue gene family member A (RhoA)-mediated calcium-independent pathway. $\mathrm{Zn}$ and $\mathrm{ZnT5}$ are also required for the translocation of PKC to the plasma membrane and the subsequent nuclear translocation of NF- $\kappa \mathrm{B}$, which leads to the production of cytokines such as interleukin-6 (IL- 6 ) and tumor necrosis factor alpha $(T N F-\alpha) . I K K \beta$ I-kappa B kinase beta, IkB $\alpha$ I-kappa B alpha 
intracellular free $\mathrm{Zn}$ concentration decreases in mouse dendritic cells exposed to the endotoxin LPS, which is a Toll-like receptor (TLR) stimulant. Furthermore, artificially depleting intracellular $\mathrm{Zn}$ with a $\mathrm{Zn}$ chelator triggers dendritic cell maturation. On the other hand, artificially elevating the intracellular $\mathrm{Zn}$ level suppresses the dendritic cells' ability to respond to LPS. LPS stimulation affects Zn transporter expression, effectively increasing (ZIP family) or decreasing (ZnT family) the level of intracellular $\mathrm{Zn}$. Importantly, the ectopic expression of ZIP6, which is reduced by LPS stimulation, suppresses dendritic cell maturation and inhibits $\mathrm{CD} 4^{+} \mathrm{T}$ cell-stimulatory activity [78]. A similar Zn effect is observed in live animals; LPS injection reduces the intracellular free $\mathrm{Zn}$ and ZIP6 mRNA levels in dendritic cells, and treatment with Zn-depleting agents increases dendritic cell maturation [78]. These results show that extracellular stimuli, by affecting $\mathrm{Zn}$ transporter expression and thus changing the intracellular $\mathrm{Zn}$ levels, play a role in the process of dendritic cell maturation, an important step in $\mathrm{T}$ cell activation and immune response (Fig. 2e).

$\mathrm{Zn}$ is also involved in $\mathrm{T}$ cell function. It has been reported that $\mathrm{Zn}$-supplying compounds such as polaprezinc and Z-103 suppress autoimmune disease models [79, 80], suggesting that $\mathrm{Zn}$ might suppress autoimmune disease by inhibiting $\mathrm{T}$ cell activation. However, the details of the mechanism behind this suppression are not understood. One of the important questions involved is how $\mathrm{Zn}$ affects T helper 17 (Th17) cells, since Th17 cell development is controlled by IL-6-induced STAT3 activation [81-85], and Th17 cells are important in autoimmune diseases such as collagen-induced arthritis (CIA), mutated IL-6 receptor and signal transducer glycoprotein 130 (gp130): Y759F gp130induced arthritis, and experimental autoimmune encephalomyelitis (EAE) [86, 87]. CIA and EAE are mediated by antigen-specific Th17 cells, whose development is controlled under STAT3 activation. As expected, adding $\mathrm{Zn}$ to drinking water significantly suppresses both CIA and EAE development in animal models [88]. Zn suppresses Th17 cell development, which is dependent on the IL-6/STAT3 signaling pathway, during the induction of autoimmune diseases (Fig. 5). In fact, Zn directly inhibits STAT3's tyrosine phosphorylation by Janus kinase without affecting the phosphorylation ability of Janus kinase proteins. STAT3 protein itself is unfolded by $\mathrm{Zn}$ binding, indicating that Zn directly binds STAT3 and inhibits its activation [88].

It has also been reported that MTs are involved in asthma and ultraviolet B-induced contact hypersensitivity. Ovalbumin-induced airway inflammation is worse in the $M T 1$ and MT2 double-KO (MT1/2-KO) mice than in wildtype mice. The cellular profile of the bronchoalveolar fluid, lung histology findings, and expression of proinflammatory

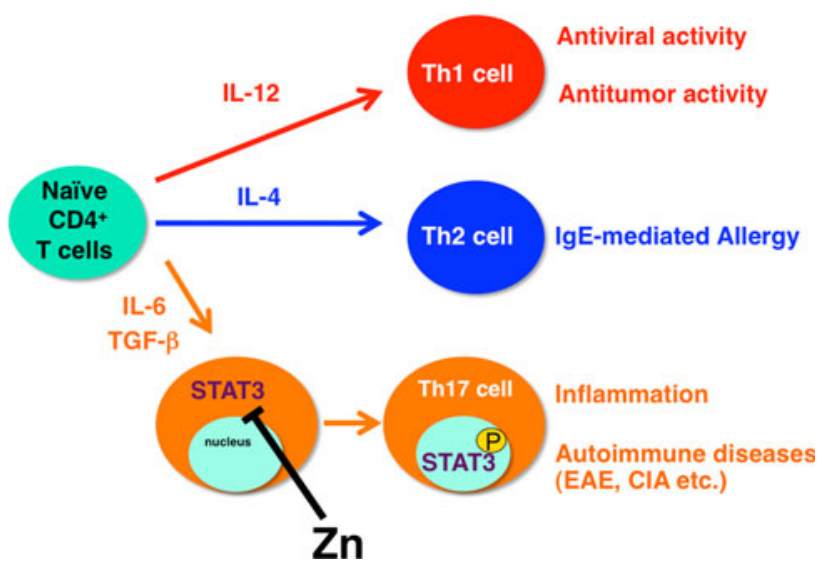

Fig. $5 \mathrm{Zn}$ suppresses $\mathrm{T}$ helper 17 (Th17) cell development by inhibiting STAT3 activation. Peripheral naive $\mathrm{CD} 4^{+} \mathrm{T}$ cell precursor cells can differentiate into three subsets of effector T cells (Th1, Th2, and Th17). The differentiation of these subsets is governed by selective cytokines, and each subset accomplishes specialized functions. Th17 cells, which are critical for the development of inflammation and autoimmune disease, are induced by IL-6 and tumor necrosis factor beta $(T G F-\beta)$. Zn directly binds STAT3, inhibiting its activation by IL- 6 and suppressing autoimmune diseases such as experimental autoimmune encephalomyelitis $(E A E)$ and collagen-induced arthritis (CIA). $P$ tyrosine phosphorylation

molecules in the lungs were consistent with increased airway inflammation in $M T 1 / 2-\mathrm{KO}$ mice [54]. In another allergy model, moderate daily ultraviolet B doses caused significantly more immunosuppression in MT1/2-KO mice than in wild-type mice [89]. These findings indicate that $\mathrm{Zn}$ transporters and Zn-related molecules are indispensably involved in allergic and immune responses and regulate a variety of signaling processes (Figs. 4, 5).

\section{Zn signaling}

As recent advances have revealed the existence of free or labile $\mathrm{Zn}$ in many physiological situations, $\mathrm{Zn}$ has been increasingly recognized as a potential signaling molecule $[15,16,19]$.

$\mathrm{Zn}$ as a neurotransmitter, or the first messenger in cellcell communication

An exchangeable $\mathrm{Zn}$ ion in the brain was first documented by Maske [90] in 1955. $\mathrm{Zn}$ is highly concentrated in synaptic vesicles and is released with glutamate in an activitydependent manner [91]. Recently, Zn-imaging techniques using fluorescence sensor molecules, which allow the $\mathrm{Zn}$ concentration and distribution to be analyzed in real time, have been widely applied [92]. Microfluorescence imaging of $\mathrm{Zn}$ secretion showed that $\mathrm{Zn}$ is released from hippocampal mossy fiber terminal vesicles into the surrounding 
milieu upon exocytotic presynaptic stimulation [93-95]. It is then taken up into the cytoplasm of neighboring cells through gated $\mathrm{Zn}$ channels. The rapid influx of $\mathrm{Zn}$ through Ca-ion-permeable $\alpha$-amino-3-hydroxy-5-methyl-4-isoxazolepropionate/kainate channels triggers the generation of reactive oxygen species (ROS) and is potentially neurotoxic [96].

In the above scenario, Zn's activity is similar to that of neurotransmitters, which are stored in membrane-enclosed synaptic vesicles, are released by exocytosis, and activate postsynaptic cells through transmitter-gated ion channels [97-99]. Since Zn modulates both the current response (mediated by excitatory and inhibitory neurotransmitter receptors) and the efficacy of transporter-driven neurotransmitter reuptake [100], synaptically released $\mathrm{Zn}$ has been proposed to function as an important regulator of synaptic transmission and plasticity [101, 102], or as an "atypical neurotransmitter" [103]. ZnT3 is highly expressed on synaptic vesicle membranes and is essential for loading $\mathrm{Zn}$ into synaptic vesicles.

Although ZnT3-KO mice show a loss of stainable $\mathrm{Zn}$ in synapses [104], they are behaviorally normal except for an enhanced susceptibility to kainite-induced seizures [105]. Recently, however, it was revealed that the ZnT3-KO mice exhibit age-dependent deficits in learning and memory that are not apparent in young animals. This age-dependent cognitive phenotype might be owing to its decreased level in the hippocampus [106]. In addition, extracellular-signalregulated kinase 1 and $2($ Erk1/2) activation is reduced in the hippocampal mossy fibers in ZnT3-KO mice, suggesting that ZnT3 is involved in the presynaptic Erk1/2 signaling required for hippocampus-dependent memory [107]. Takeda et al. [17] reported that $\mathrm{Zn}$ chelation with clioquinol inhibits hippocampal long-term potentiation and cognitive behavior. This evidence suggests that synaptic $\mathrm{Zn}$ acts as a neurotransmitter for maintaining the synaptic environment.

$\mathrm{Zn}$ has been identified as an endogenous GPCR 39 (GPR39) agonist, and the concept that GPR39 is the Znsensing receptor in the brain is consistent with $\mathrm{Zn}$ 's role as a neurotransmitter or first messenger [108, 109]. Intercellular $\mathrm{Zn}$ communication mediated through the Zn-sensing GPR39 is also involved in regulating epithelial cell repair [110] and endocrine pancreatic function [111]. Also supporting Zn's role in neurotransmission, Hosie et al. [112] identified two Zn-binding sites and characterized a third in the $\gamma$-aminobutyric acid receptor, using site-directed mutagenesis. In addition, Hirzel et al. [113] produced knock-in mice carrying the mutation D80A (a constructed Zn-binding site) in the glycine receptor alphal subunit gene to show that $\mathrm{Zn}$ modulates neurotransmission. It is also known that $\mathrm{Zn}$ inhibits $N$-methyl-D-aspartate receptor activity through a dual mechanism, a voltage-dependent channel block and a voltage-independent reduction in the probability of the channel opening [114-116]. Thus, it is likely that $\mathrm{Zn}$ acts as a neurotransmitter in addition to its other roles in the neural system.

$\mathrm{Zn}$ as an intracellular signaling molecule, or the second messenger

Several intracellular second messengers have been identified, including $3^{\prime}, 5^{\prime}$-cyclic adenosine monophosphate (cAMP), $\mathrm{Ca}^{2+}, 3^{\prime}, 5^{\prime}$-cyclic guanosine monophosphate (cGMP), nitric oxide (NO), ROS, and lipid mediators [117]. $\mathrm{Zn}$ has also appeared as a potential intracellular signaling molecule in mitosis in starfish oocytes [118]. Recently, an essential role for $\mathrm{Zn}$ in arresting second metaphase exit has been reported. This suggests that $\mathrm{Zn}$ has the potential to act as an intracellular signaling molecule to regulate the developmental program in vertebrate fertilization $[4,5]$. It has also been reported that $\mathrm{Zn}$ itself affects a variety of signaling molecules, including $\mathrm{PKC}, \mathrm{Ca} /$ calmodulindependent protein kinase II, Erk1/2, cAMP-dependent protein kinase, protein tyrosine phosphatase, and caspase- 3 [119-125]. In addition, Zn activates ion channels such as the transient receptor potential ankyrin 1 [126, 127], ATPsensitive $\mathrm{K}^{+}$[128], and large-conductance Ca-activated $\mathrm{K}^{+}$ [129] channels. Together, these findings suggest that $\mathrm{Zn}$ may function as an intracellular signaling molecule or second messenger, if extracellular stimuli such as cytokines and growth factors cause the intracellular $\mathrm{Zn}$ status to change, either independently, or in a manner dependent on the transcriptional changes of $\mathrm{Zn}$ transporters or MTs.

We have proposed that $\mathrm{Zn}$ signaling can be divided into EZS, which is directly and rapidly induced by an extracellular stimulus, and LZS, which depends on transcriptional changes to MTs, Zn transporters, and other Zn-related molecules [19] (Fig. 3). ZIP6/Liv1 is required for the epithelial-mesenchymal transition in the zebrafish gastrula organizer, because it is essential for the nuclear retention of the E-cadherin repressor Snail (Fig. 2a) [20]. Since ZIP6/Liv1 expression in the zebrafish organizer is dependent on STAT3 activation, any extracellular stimulus regulating STAT3 activation could change the intracellular $\mathrm{Zn}$ level by inducing changes in $\mathrm{Zn}$ transporters such as ZIP6/Liv1. TLR4 also alters the intracellular free Zn level, which it decreases by inducing changes in $\mathrm{Zn}$ transporter expression in dendritic cells (Fig. 2e) [78] and in pulmonary endothelial cells [130]. These observations support the idea that $\mathrm{Zn}$ acts as an intracellular second messenger, that is, as a molecule whose intracellular status is altered in response to an extracellular stimulus and that is capable of transducing the extracellular stimulus into an intracellular signaling event.

The role of $\mathrm{Zn}$ as a second messenger is further supported by our findings that ZIP13 is required for the BMP/ 
TGF- $\beta$-induced nuclear localization of Smad proteins (Fig. 2b) [23], that ZIP14 is involved in GPCR-mediated signal transduction through cAMP basal level regulation (Fig. 2c) [36], and that Fc\&RI-stimulation-induced PKC activation is dependent on ZnT5 in mast cells (Fig. 2d) [43]. Another example showing that $\mathrm{Zn}$ transporters are involved in signaling pathways is that cation diffusion facilitator 1, a structural homologue of ZnT1 in Caenorhabditis elegans, might mediate Raf-1 activation by directly interacting with Raf-1 and removing Zn from the Raf-1 cysteine-rich domain [131]. Thus, extracellular stimuli can affect intracellular signaling pathways by changing the intracellular $\mathrm{Zn}$ status through changes in the expression of $\mathrm{Zn}$ transporters and other $\mathrm{Zn}$-related molecules; this exemplifies the LZS type (Fig. 3) [19].

EZS, on the other hand, is exemplified by the transcription-independent increase in intracellular $\mathrm{Zn}$ level that occurs in mast cells some minutes after extracellular stimulation; we call this phenomenon a "Zn wave" (Fig. 6) [21]. The $\mathrm{Zn}$ wave originates from the region of the endoplasmic reticulum and depends on $\mathrm{Ca}^{2+}$ influx and Erk1/2 activation in mast cells (Fig. 6b). Since extracellular $\mathrm{Zn}$ is not involved in the $\mathrm{Zn}$ wave, and it is induced within several minutes of Fc\&RI stimulation, $\mathrm{Zn}$ here acts as an intracellular signaling molecule (Fig. 6). Using the $\mathrm{Zn}$ probe FluoZin-3, Haase et al. [132] revealed that the intracellular $\mathrm{Zn}$ level is elevated in peripheral blood mononuclear cells after phorbol 12-myristate 13-acetate stimulation, and in human leukocytes, especially monocytes, with physiological stimulation [133]. In addition, ZIP7 is reported to regulate intracellular $\mathrm{Zn}$ on the endoplasmic reticulum membrane [134]. It is also possible that transporters and channels other than ZIP or ZnT family members generate $\mathrm{Zn}$ waves in individual cell types with various types of stimulation. In any case, the precise molecular mechanisms generating the $\mathrm{Zn}$ wave are still elusive (Fig. 7a).

Outside intracellular compartments, Zn-buffering proteins such as MTs are believed to be a major source of free $\mathrm{Zn}$ released into the cytosol space in response to an extracellular stimulus [135-137]. $\mathrm{Zn}$ is rapidly released from MTs by nitrosylation or by thiol ligand oxidation. Ultraviolet A irradiation can induce the generation of ROS, which might oxidize thiols in MTs and induce transient increases in intracellular free $\mathrm{Zn}$ level [138]. In pathological situations, $\mathrm{N}$-methyl-D-aspartate receptor activation might induce endogenous NO synthesis and increase intracellular free $\mathrm{Zn}$ level by liberating Zn from MTs [139]. The liberation of intracellular $\mathrm{Zn}$ and the overactivation of potassium channels were proposed to be important components of nitrosative stress-induced neuronal death [140]. The liberated $\mathrm{Zn}$ induces its toxicity to neurons via activation of 12-lipoxygenase and mitogen-activated protein
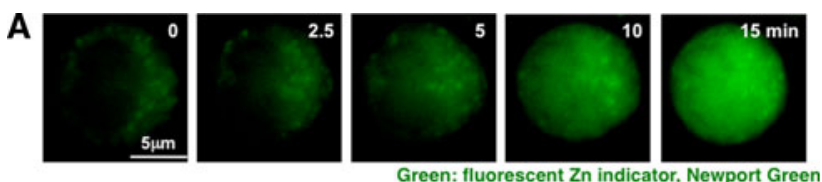

B

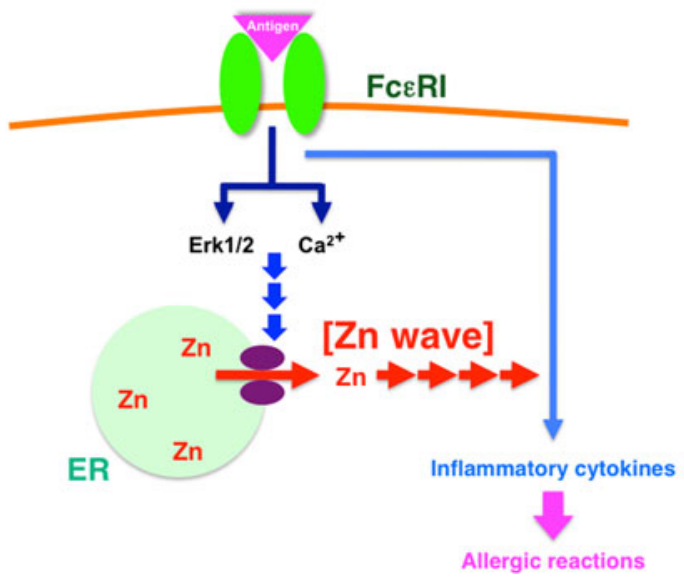

Fig. 6 Fc\&RI increases intracellular free $\mathrm{Zn}$ levels, $\mathrm{Zn}$ wave: a type of early $\mathrm{Zn}$ signaling. a The intracellular $\mathrm{Zn}$ level increases within several minutes after antigen stimulation. To monitor the intracellular $\mathrm{Zn}$ level, mast cells were treated with the cell-permeable fluorescent $\mathrm{Zn}$ indicator Newport Green. Newport Green fluorescence remained steady in the cytoplasm, but gradually increased in the perinuclear and nuclear areas upon FceRI stimulation. We named this phenomenon a "Zn wave." b Early Zn signaling in mast cells. Extracellular antigen stimulation induces a $\mathrm{Zn}$ wave-a rapid alteration in intracellular $\mathrm{Zn}$ level-through the activation of $\mathrm{Ca}^{2+}$ and extracellular-signal-regulated kinase 1 and 2 (Erk1/2) signaling, which might positively affect the signal for inflammatory cytokine-mediated allergic reactions. This suggests that $\mathrm{Zn}$ has a role as an intracellular signaling molecule, transducing extracellular stimuli to physiological responses. Violet ovals $\mathrm{Zn}$ gatekeepers. (a Modified from Yamasaki et al. [21])

kinase [141]. The NO donor $S$-nitrosocysteine (SNOC) both increases free $\mathrm{Zn}$ level and inhibits LPS-induced tumor necrosis factor alpha and interleukin-1 beta release. This SNOC-induced increase in intracellular free $\mathrm{Zn}$ level may therefore mediate SNOC's inhibitory effect via increased cGMP level [142]. In addition, cytokine stimulation sometimes induces NO production, thereby enhancing the intracellular free $\mathrm{Zn}$ level [143]. These reports indicate that $\mathrm{Zn}$ released from oxidative-reactionstimulated MTs contributes to the EZS-type regulation of intracellular phenomena (Fig. 7b).

\section{Conclusion and future prospects}

As discussed in this review, $\mathrm{Zn}$ is clearly involved in regulating a wide variety of physiological responses. Although most $\mathrm{Zn}$ studies have focused on the general maintenance of its homeostasis, recent studies have shown that $\mathrm{Zn}$ 's functions are far more extensive than might be 
Fig. 7 Model for $\mathrm{Zn}$ release for the generation of $\mathrm{Zn}$ signaling. a Labile $\mathrm{Zn}$ in intracellular $\mathrm{Zn}$ storage moves through " $\mathrm{Zn}$ gatekeepers" into the cytosol, and approaches target molecules. The $\mathrm{Zn}$ gatekeepers are closed in the steady state, but are opened by changes in activation status. b Most of the $\mathrm{Zn}$ in the cytosol is sequestered in MTs, and is detached from the MTs by intracellular oxidative stress. The rapid increase in intracellular $\mathrm{Zn}$ mediated by cellular events may act as an early $\mathrm{Zn}$ signaling to change the status of target molecules

\section{A "Gatekeeper" releases $\mathrm{Zn}$ from intracellular $\mathrm{Zn}$ storage}

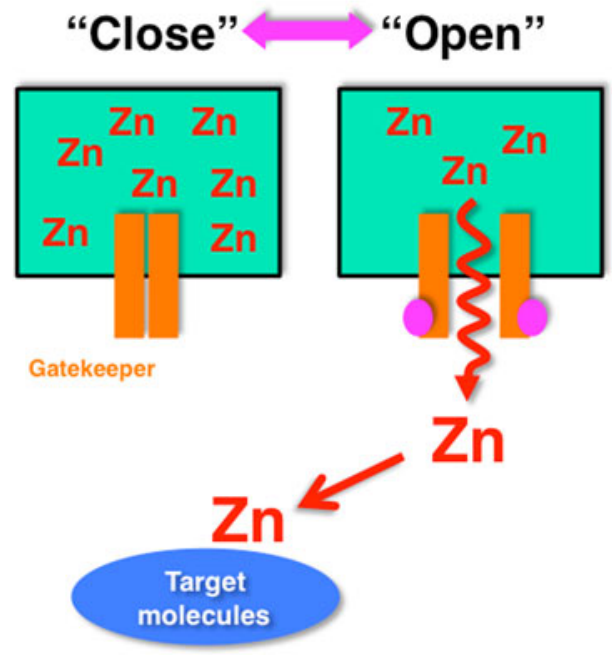

B

\section{$\mathrm{Zn}$ is detached from MTs by oxidative stress}

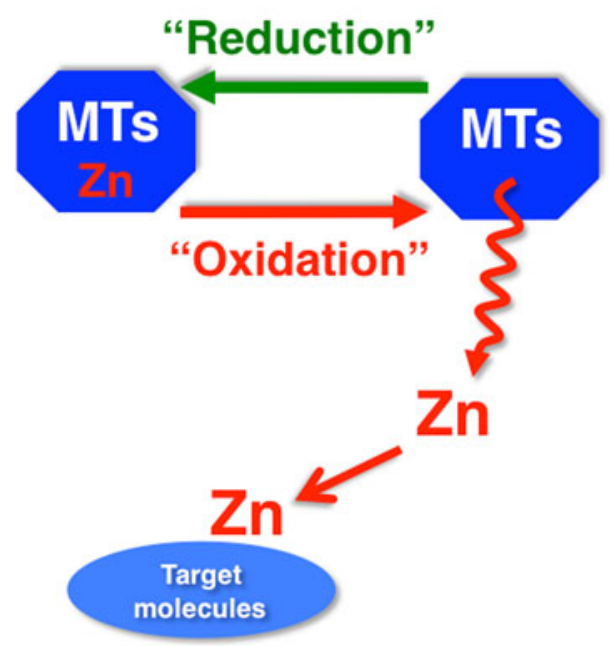

implied by its simple definition as an essential nutrient. The intracellular $\mathrm{Zn}$ status is dynamically altered in response to a variety of extracellular stimuli, and this change in $\mathrm{Zn}$ status is capable of transducing extracellular stimuli into intracellular signaling events. On the basis of the evidence accumulated, we have proposed that $\mathrm{Zn}$ acts as a signaling molecule in at least two modes: transcription-independent EZS and transcription-dependent LZS (Fig. 3) [19]. Several important questions remain to be resolved: What extracellular stimulus, in which cells or tissues, regulates the expression of the $\mathrm{Zn}$ transporters and channels involved in $\mathrm{Zn}$ signaling? How are these $\mathrm{Zn}$ transporters or channels activated in response to the extracellular stimulus? How does each $\mathrm{Zn}$ transporter specifically regulate the intracellular signaling pathway? How do $\mathrm{Zn}$ transporters transfer $\mathrm{Zn}$ into their target molecules? Is there any chaperon which transfers $\mathrm{Zn}$ from a given transporter to its specific target molecule? What are the target molecules and biological roles of $\mathrm{Zn}$ signaling? Another question is how to specifically monitor and visualize intracellular free $\mathrm{Zn}$ in vivo with high resolution; this will require the use of chemical compounds [92], multitracer detection devices [144], and two-photon and X-ray fluorescence microscopy $[145,146]$. The development of drugs for Zn-related diseases is another emerging avenue of study. Modified Zn-containing pharmaceuticals may speed the discovery of $\mathrm{Zn}$-signaling action points [147]. A deeper understanding of the early and late $\mathrm{Zn}$ signals and signaling dysfunctions will provide novel insights into Zn's roles as a signaling molecule in mammalian health and diseases.

Acknowledgments We thank Masami Kawamura, Ayumi Ito, and Mayumi Hara for their indispensable support. We also thank Mizuki
Shimura and Ryoko Masuda for their secretarial assistance. This work was supported by KAKENHI and the JST-CREST program.

Open Access This article is distributed under the terms of the Creative Commons Attribution Noncommercial License which permits any noncommercial use, distribution, and reproduction in any medium, provided the original author(s) and source are credited.

\section{References}

1. Raulin J (1869) Annales des sciences naturelles. Botanique et biologie végétale 11:93-345

2. Prasad AS, Halsted JA, Nadimi M (1961) Am J Med 31:532-546

3. Hershfinkel M, Aizenman E, Andrews G, Sekler I (2010) Sci Signal 3:mr2

4. Kim AM, Vogt S, O'Halloran TV, Woodruff TK (2010) Nat Chem Biol 6:674-681

5. Suzuki T, Yoshida N, Suzuki E, Okuda E, Perry AC (2010) Development 137:2659-2669

6. Vallee BL, Falchuk KH (1993) Physiol Rev 73:79-118

7. Prasad AS (1995) Nutrition 11:93-99

8. Andreini C, Banci L, Bertini I, Rosato A (2006) J Proteome Res 5:196-201

9. Eide DJ (2004) Pflugers Arch 447:796-800

10. Palmiter RD, Huang L (2004) Pflugers Arch 447:744-751

11. Vallee BL (1995) Neurochem Int 27:23-33

12. Andrews GK (2001) Biometals 14:223-237

13. Palmiter RD (2004) Proc Natl Acad Sci USA 101:4918-4923

14. Lichtlen P, Schaffner W (2001) Bioessays 23:1010-1017

15. Frederickson CJ, Koh JY, Bush AI (2005) Nat Rev Neurosci 6:449-462

16. Sensi SL, Paoletti P, Bush AI, Sekler I (2009) Nat Rev Neurosci 10:780-791

17. Takeda A, Takada S, Ando M, Itagaki K, Tamano H, Suzuki M, Iwaki H, Oku N (2010) Neuroscience 171:443-450

18. Takeda A, Tamano H, Imano S, Oku N (2010) Neuroscience 168:715-722 
19. Hirano T, Murakami M, Fukada T, Nishida K, Yamasaki S, Suzuki T (2008) Adv Immunol 97:149-176

20. Yamashita S, Miyagi C, Fukada T, Kagara N, Che YS, Hirano T (2004) Nature 429:298-302

21. Yamasaki S, Sakata-Sogawa K, Hasegawa A, Suzuki T, Kabu K, Sato E, Kurosaki T, Yamashita S, Tokunaga M, Nishida K, Hirano T (2007) J Cell Biol 177:637-645

22. Murakami M, Hirano T (2008) Cancer Sci 99:1515-1522

23. Fukada T, Civic N, Furuichi T, Shimoda S, Mishima K, Higashiyama H, Idaira Y, Asada Y, Kitamura H, Yamasaki S, Hojyo S, Nakayama M, Ohara O, Koseki H, Dos Santos HG, Bonafe L, Ha-Vinh R, Zankl A, Unger S, Kraenzlin ME, Beckmann JS, Saito I, Rivolta C, Ikegawa S, Superti-Furga A, Hirano T (2008) PLoS One 3:e3642

24. Fukada T, Asada Y, Mishima K, Shimoda S, Saito I (2011) J Oral Biosci 53:1-12

25. Ibs KH, Rink L (2003) J Nutr 133:1452S-1456S

26. Telford WG, Fraker PJ (1995) J Cell Physiol 164:259-270

27. Rink L, Gabriel P (2000) Proc Nutr Soc 59:541-552

28. Blindauer CA, Leszczyszyn OI (2010) Nat Prod Rep 27:720-741

29. Fukada T, Kambe T (2011) Metallomics. doi:10.1039/C1MT $00011 \mathrm{~J}$

30. Kambe T, Yamaguchi-Iwai Y, Sasaki R, Nagao M (2004) Cell Mol Life Sci 61:49-68

31. Dufner-Beattie J, Huang ZL, Geiser J, Xu W, Andrews GK (2005) Mol Cell Biol 25:5607-5615

32. Dufner-Beattie J, Huang ZL, Geiser J, Xu W, Andrews GK (2006) Genesis 44:239-251

33. Kury S, Dreno B, Bezieau S, Giraudet S, Kharfi M, Kamoun R, Moisan JP (2002) Nat Genet 31:239-240

34. Wang K, Zhou B, Kuo YM, Zemansky J, Gitschier J (2002) Am J Hum Genet 71:66-73

35. Giunta C, Elcioglu NH, Albrecht B, Eich G, Chambaz C, Janecke AR, Yeowell H, Weis M, Eyre DR, Kraenzlin M, Steinmann B (2008) Am J Hum Genet 82:1290-1305

36. Hojyo S, Fukada T, Shimoda S, Ohashi W, Bin B-H, Koseki H, Hirano T (2011) PLoS One 6:e18059

37. Huang L, Gitschier J (1997) Nat Genet 17:292-297

38. Chowanadisai W, Lonnerdal B, Kelleher SL (2006) J Biol Chem 281:39699-39707

39. Chimienti F, Favier A, Seve M (2005) Biometals 18:313-317

40. Sladek R, Rocheleau G, Rung J, Dina C, Shen L, Serre D, Boutin P, Vincent D, Belisle A, Hadjadj S, Balkau B, Heude B, Charpentier G, Hudson TJ, Montpetit A, Pshezhetsky AV, Prentki M, Posner BI, Balding DJ, Meyre D, Polychronakos C, Froguel P (2007) Nature 445:881-885

41. Pound LD, Sarkar SA, Benninger RK, Wang Y, Suwanichkul A, Shadoan MK, Printz RL, Oeser JK, Lee CE, Piston DW, McGuinness OP, Hutton JC, Powell DR, O'Brien RM (2009) Biochem J 421:371-376

42. Inoue K, Matsuda K, Itoh M, Kawaguchi H, Tomoike H, Aoyagi T, Nagai R, Hori M, Nakamura Y, Tanaka T (2002) Hum Mol Genet 11:1775-1784

43. Nishida K, Hasegawa A, Nakae S, Oboki K, Saito H, Yamasaki S, Hirano T (2009) J Exp Med 206:1351-1364

44. Kambe T, Suzuki T, Nagao M, Yamaguchi-Iwai Y (2006) Genomics Proteomics Bioinformatics 4:1-9

45. Mathews WR, Ong D, Milutinovich AB, Van Doren M (2006) Development 133:1143-1153

46. Pielage J, Kippert A, Zhu M, Klambt C (2004) Dev Biol 275:245-257

47. Van Doren M, Mathews WR, Samuels M, Moore LA, Broihier HT, Lehmann R (2003) Development 130:2355-2364

48. Kagara N, Tanaka N, Noguchi S, Hirano T (2007) Cancer Sci 98:692-697
49. Stathakis DG, Burton DY, McIvor WE, Krishnakumar S, Wright TR, O'Donnell JM (1999) Genetics 153:361-382

50. Hsouna A, Lawal HO, Izevbaye I, Hsu T, O’Donnell JM (2007) Dev Biol 308:30-43

51. Hogstrand C, Kille P, Nicholson RI, Taylor KM (2009) Trends Mol Med 15:101-111

52. Margoshes M, Vallee BL (1957) J Am Chem Soc 79:48134814

53. Inoue K, Takano H, Shimada A, Wada E, Yanagisawa R, Sakurai M, Satoh M, Yoshikawa T (2006) FASEB J 20: 533-535

54. Inoue K, Takano H, Yanagisawa R, Sakurai M, Ichinose T, Sadakane K, Hiyoshi K, Sato M, Shimada A, Inoue M, Yoshikawa T (2005) Exp Biol Med (Maywood) 230:75-81

55. Penkowa M, Espejo C, Martinez-Caceres EM, Poulsen CB, Montalban X, Hidalgo J (2001) J Neuroimmunol 119:248-260

56. Tran CD, Huynh H, van den Berg M, van der Pas M, Campbell MA, Philcox JC, Coyle P, Rofe AM, Butler RN (2003) Helicobacter 8:533-541

57. Takano H, Inoue K, Yanagisawa R, Sato M, Shimada A, Morita T, Sawada M, Nakamura K, Sanbongi C, Yoshikawa T (2004) Thorax 59:1057-1062

58. Inoue K, Takano H, Shimada A, Satoh M (2009) Mediators Inflamm 2009:101659

59. Prasad AS (2008) Mol Med 14:353-357

60. Fernandes G, Nair M, Onoe K, Tanaka T, Floyd R, Good RA (1979) Proc Natl Acad Sci USA 76:457-461

61. Prasad AS (1991) Am J Clin Nutr 53:403-412

62. Shankar AH, Prasad AS (1998) Am J Clin Nutr 68:447S-463S

63. Keen CL, Gershwin ME (1990) Annu Rev Nutr 10:415-431

64. Fraker PJ, King LE (2004) Annu Rev Nutr 24:277-298

65. Ho LH, Ruffin RE, Murgia C, Li L, Krilis SA, Zalewski PD (2004) J Immunol 172:7750-7760

66. Truong-Tran AQ, Ruffin RE, Zalewski PD (2000) Am J Physiol Lung Cell Mol Physiol 279:L1172-L1183

67. Lansdown AB, Mirastschijski U, Stubbs N, Scanlon E, Agren MS (2007) Wound Repair Regen 15:2-16

68. Lansdown AB (1996) Lancet 347:706-707

69. Schwartz JR, Marsh RG, Draelos ZD (2005) Dermatol Surg 31:837-847 (discussion 847)

70. Richter M, Bonneau R, Girard MA, Beaulieu C, Larivee P (2003) Chest 123:446S

71. Riccioni G, D’Orazio N (2005) Expert Opin Investig Drugs 14:1145-1155

72. Zalewski PD, Truong-Tran AQ, Grosser D, Jayaram L, Murgia C, Ruffin RE (2005) Pharmacol Ther 105:127-149

73. Xu TF, Wang XL, Yang JZ, Hu XY, Wu WF, Guo L, Kang LD, Zhang LY (2009) Pediatr Pulmonol 44:763-767

74. Kabu K, Yamasaki S, Kamimura D, Ito Y, Hasegawa A, Sato E, Kitamura H, Nishida K, Hirano T (2006) J Immunol 177: 1296-1305

75. Richter M, Cantin AM, Beaulieu C, Cloutier A, Larivee P (2003) Am J Physiol Lung Cell Mol Physiol 285:L719-L729

76. Corbalan-Garcia S, Gomez-Fernandez JC (2006) Biochim Biophys Acta 1761:633-654

77. Bernal PJ, Bauer EM, Cao R, Maniar S, Mosher M, Chen J, Wang QJ, Glorioso JC, Pitt BR, Watkins SC, St Croix CM (2011) Am J Physiol Lung Cell Mol Physiol. doi:10.1152/ ajplung.00328.2010

78. Kitamura H, Morikawa H, Kamon H, Iguchi M, Hojyo S, Fukada T, Yamashita S, Kaisho T, Akira S, Murakami M, Hirano T (2006) Nat Immunol 7:971-977

79. Ohkawara T, Takeda H, Kato K, Miyashita K, Kato M, Iwanaga T, Asaka M (2005) Scand J Gastroenterol 40:1321-1327

80. Tran CD, Ball JM, Sundar S, Coyle P, Howarth GS (2007) Dig Dis Sci 52:2113-2121 
81. Bettelli E, Korn T, Kuchroo VK (2007) Curr Opin Immunol 19:652-657

82. Hirano T (1998) Int Rev Immunol 16:249-284

83. Ivanov II, McKenzie BS, Zhou L, Tadokoro CE, Lepelley A, Lafaille JJ, Cua DJ, Littman DR (2006) Cell 126:11211133

84. Nishihara M, Ogura H, Ueda N, Tsuruoka M, Kitabayashi C, Tsuji F, Aono H, Ishihara K, Huseby E, Betz UA, Murakami M, Hirano T (2007) Int Immunol 19:695-702

85. Veldhoen M, Stockinger B (2006) Trends Immunol 27:358-361

86. Ogura H, Murakami M, Okuyama Y, Tsuruoka M, Kitabayashi C, Kanamoto M, Nishihara M, Iwakura Y, Hirano T (2008) Immunity 29:628-636

87. Bettelli E, Oukka M, Kuchroo VK (2007) Nat Immunol $8: 345-350$

88. Kitabayashi C, Fukada T, Kanamoto M, Ohashi W, Hojyo S, Atsumi T, Ueda N, Azuma I, Hirota H, Murakami M, Hirano T (2010) Int Immunol 22:375-386

89. Reeve VE, Nishimura N, Bosnic M, Michalska AE, Choo KH (2000) Immunology 100:399-404

90. Maske H (1955) Klin Wochenschr 33:1058

91. Assaf SY, Chung SH (1984) Nature 308:734-736

92. Kikuchi K (2010) Chem Soc Rev 39:2048-2053

93. Li Y, Hough CJ, Suh SW, Sarvey JM, Frederickson CJ (2001) J Neurophysiol 86:2597-2604

94. Qian J, Noebels JL (2005) J Physiol 566:747-758

95. Ueno S, Tsukamoto M, Hirano T, Kikuchi K, Yamada MK, Nishiyama N, Nagano T, Matsuki N, Ikegaya Y (2002) J Cell Biol 158:215-220

96. Weiss JH, Sensi SL (2000) Trends Neurosci 23:365-371

97. Xie X, Smart TG (1994) Pflugers Arch 427:481-486

98. Hershfinkel M, Moran A, Grossman N, Sekler I (2001) Proc Natl Acad Sci USA 98:11749-11754

99. Colvin RA, Fontaine CP, Laskowski M, Thomas D (2003) Eur J Pharmacol 479:171-185

100. Smart TG, Hosie AM, Miller PS (2004) Neuroscientist 10:432-442

101. Lu YM, Taverna FA, Tu R, Ackerley CA, Wang YT, Roder J (2000) Synapse 38:187-197

102. Vogt K, Mellor J, Tong G, Nicoll R (2000) Neuron 26:187-196

103. Baranano DE, Ferris CD, Snyder SH (2001) Trends Neurosci 24:99-106

104. Cole TB, Wenzel HJ, Kafer KE, Schwartzkroin PA, Palmiter RD (1999) Proc Natl Acad Sci USA 96:1716-1721

105. Lopantsev V, Wenzel HJ, Cole TB, Palmiter RD, Schwartzkroin PA (2003) Neuroscience 116:237-248

106. Adlard PA, Parncutt JM, Finkelstein DI, Bush AI (2010) J Neurosci 30:1631-1636

107. Sindreu C, Palmiter RD, Storm DR (2011) Proc Natl Acad Sci USA 108:3366-3370

108. Yasuda S, Miyazaki T, Munechika K, Yamashita M, Ikeda Y, Kamizono A (2007) J Recept Signal Transduct Res 27:235-246

109. Besser L, Chorin E, Sekler I, Silverman WF, Atkin S, Russell JT, Hershfinkel M (2009) J Neurosci 29:2890-2901

110. Sharir H, Zinger A, Nevo A, Sekler I, Hershfinkel M (2010) J Biol Chem 285:26097-26106

111. Holst B, Egerod KL, Jin C, Petersen PS, Ostergaard MV, Hald J, Sprinkel AM, Storling J, Mandrup-Poulsen T, Holst JJ, Thams P, Orskov C, Wierup N, Sundler F, Madsen OD, Schwartz TW (2009) Endocrinology 150:2577-2585

112. Hosie AM, Dunne EL, Harvey RJ, Smart TG (2003) Nat Neurosci 6:362-369

113. Hirzel K, Muller U, Latal AT, Hulsmann S, Grudzinska J, Seeliger MW, Betz H, Laube B (2006) Neuron 52:679-690

114. Mayer ML, Vyklicky L Jr (1989) J Physiol 415:351-365

115. Christine CW, Choi DW (1990) J Neurosci 10:108-116
116. Legendre P, Westbrook GL (1990) J Physiol 429:429-449

117. Gomperts BD, Tatham PER, Kramer IM (2002) Signal transduction. Academic Press, San Diego

118. Fujii T (1954) Nature 174:1108-1109

119. Hubbard SR, Bishop WR, Kirschmeier P, George SJ, Cramer SP, Hendrickson WA (1991) Science 254:1776-1779

120. Lengyel I, Fieuw-Makaroff S, Hall AL, Sim AT, Rostas JA, Dunkley PR (2000) J Neurochem 75:594-605

121. Murakami K, Whiteley MK, Routtenberg A (1987) J Biol Chem 262:13902-13906

122. Park JA, Koh JY (1999) J Neurochem 73:450-456

123. Brautigan DL, Bornstein P, Gallis B (1981) J Biol Chem 256:6519-6522

124. Haase H, Maret W (2005) Biometals 18:333-338

125. Perry DK, Smyth MJ, Stennicke HR, Salvesen GS, Duriez P, Poirier GG, Hannun YA (1997) J Biol Chem 272:1853018533

126. Andersson DA, Gentry C, Moss S, Bevan S (2009) Proc Natl Acad Sci USA 106:8374-8379

127. Hu H, Bandell M, Petrus MJ, Zhu MX, Patapoutian A (2009) Nat Chem Biol 5:183-190

128. Prost AL, Bloc A, Hussy N, Derand R, Vivaudou M (2004) J Physiol 559:157-167

129. Hou S, Vigeland LE, Zhang G, Xu R, Li M, Heinemann SH, Hoshi T (2010) J Biol Chem 285:6434-6442

130. Thambiayya K, Wasserloos KJ, Huang Z, Kagan VE, St Croix CM, Pitt BR (2011) Am J Physiol Lung Cell Mol Physiol 300:L624-L632

131. Jirakulaporn T, Muslin AJ (2004) J Biol Chem 279:2780727815

132. Haase H, Hebel S, Engelhardt G, Rink L (2006) Anal Biochem 352:222-230

133. Haase H, Ober-Blobaum JL, Engelhardt G, Hebel S, Heit A, Heine H, Rink L (2008) J Immunol 181:6491-6502

134. Taylor KM, Vichova P, Jordan N, Hiscox S, Hendley R, Nicholson RI (2008) Endocrinology 149:4912-4920

135. Maret W (2000) J Nutr 130:1455S-1458S

136. Maret W (2006) Antioxid Redox Signal 8:1419-1441

137. Maret W, Li Y (2009) Chem Rev 109:4682-4707

138. Pirev E, Calles C, Schroeder P, Sies H, Kroncke KD (2008) Free Radic Biol Med 45:86-91

139. Bossy-Wetzel E, Talantova MV, Lee WD, Scholzke MN, Harrop A, Mathews E, Gotz T, Han J, Ellisman MH, Perkins GA, Lipton SA (2004) Neuron 41:351-365

140. Pal S, He K, Aizenman E (2004) Pflugers Arch 448:296-303

141. Zhang Y, Aizenman E, DeFranco DB, Rosenberg PA (2007) Mol Med 13:350-355

142. von Bulow V, Rink L, Haase H (2005) J Immunol 175: 4697-4705

143. Spahl DU, Berendji-Grun D, Suschek CV, Kolb-Bachofen V, Kroncke KD (2003) Proc Natl Acad Sci USA 100:1395213957

144. Kanayama Y, Tsuji T, Enomoto S, Amano R (2005) Biometals 18:553-565

145. Fahrni CJ (2007) Curr Opin Chem Biol 11:121-127

146. Sumalekshmy S, Henary MM, Siegel N, Lawson PV, Wu Y, Schmidt K, Bredas JL, Perry JW, Fahrni CJ (2007) J Am Chem Soc 129:11888-11889

147. Sakurai H, Yoshikawa Y, Yasui H (2008) Chem Soc Rev 37:2383-2392

148. Begum NA, Kobayashi M, Moriwaki Y, Matsumoto M, Toyoshima K, Seya T (2002) Genomics 80:630-645

149. Taylor KM, Nicholson RI (2003) Biochim Biophys Acta 1611:16-30

150. Chimienti F, Devergnas S, Favier A, Seve M (2004) Diabetes 53:2330-2337 
151. Wang F, Kim BE, Petris MJ, Eide DJ (2004) J Biol Chem 279:51433-51441

152. Huang L, Kirschke CP, Zhang Y, Yu YY (2005) J Biol Chem 280:15456-15463
153. Kelleher SL, Lonnerdal B (2005) Am J Physiol Cell Physiol 288:C1042-C1047

154. Taylor KM, Morgan HE, Johnson A, Nicholson RI (2005) FEBS Lett 579:427-432 